\title{
Integrated Cave Stability Assessment: A Case Study at Naga Mas Cave, Mount Pua, Kinta Valley, Ipoh, Perak, Malaysia
}

(Penilaian Kestabilan Gua Integrasi: Kajian Kes di Gua Naga Mas, Bukit Pua, Lembah Kinta, Ipoh, Perak, Malaysia)

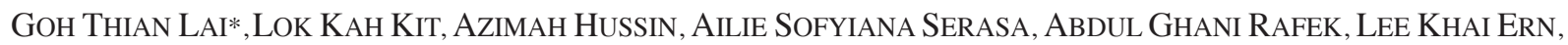 \\ Tuan Rusli MOHAmed, ShaO LeI, YANLONG CHEN \& Mingwei ZHANG
}

\begin{abstract}
Naga Mas Cave, a natural cave which also houses a temple is becoming one of the popular places of worship for Buddhist community in Ipoh, Perak. With the increasing number of worshippers entering the cave, the stability of this cave becomes important. With that in mind, an assessment on natural cave stability was conducted in the interest of public safety. Slope Mass Rating (SMR), $Q$ rock mass classification system and cave roof thickness-width ratio of cave were employed in this assessment. The lithology of study area consists of dolomitic limestone. Discontinuity surveys were conducted at two slopes, labeled C1 and C2. For slope C1, three (3) joint sets J1, J2 and J3 with the dip direction and angles of 332\% $49^{\circ}$, $154^{\circ} / 37^{\circ}$ and $049^{\circ} / 80^{\circ}$, respectively, were identified. While slope C2 has four (4) sets of joints J1, J2, J3 and J4 with the dip direction and angles of $323^{\circ} / 44^{\circ}, 125^{\circ} / 57^{\circ}, 42^{\circ} / 76^{\circ}, 263^{\circ} / 67^{\circ}$, respectively. The relationship between the rock quality, $Q$ values and cave width shows that all parts inside the cave need support except for the cave chamber at the northern part. As for the cave wall stability, the northern part of the south east wall, south eastern and southern part as well as the north western wall and south western corner were classified as poor slope class due to the unfavorable orientation of the cave wall. Ratio of cave roof thickness and cave width shows that the cave is stable. From the results, a mitigation plan is proposed to highlight the cave safety zone to ensure the safety of worshippers and public visiting the cave.
\end{abstract}

Keywords: Cave roof thickness; cave stability; mitigation; Q-system; Slope Mass Rating (SMR)

\section{ABSTRAK}

Gua Naga Mas, sebuah gua semula jadi yang juga menempatkan sebuah kuil telah menjadi salah satu tempat ibadat popular bagi masyarakat Buddha di Ipoh, Perak. Dengan semakin banyak penganut agama Buddha memasuki gua, tahap kestabilan gua ini menjadi penting. Dengan itu, satu penilaian terhadap kestabilan gua semula jadi dilakukan demi kepentingan keselamatan awam. Perkadaran Jasad Cerun (SMR), sistem pengelasan jasad batuan Q dan nisbah ketebalan bumbung-lebar gua telah digunakan dalam penilaian ini. Litologi kawasan kajian terdiri daripada batu kapur dolomit. Tinjauan ketakselanjaran dijalankan pada dua cerun, yang dilabelkan C1 dan C2. Untuk cerun C1, tiga (3) set kekar J1, J2 dan J3 dengan arah kemiringan dan sudut kemiringan iaitu masing-masing $332^{\circ} / 49^{\circ}$, $154^{\circ} / 37^{\circ}$ dan $049^{\circ} / 80^{\circ}$ telah dikenal pasti. Manakala cerun C2 mempunyai empat (4) set kekar J1, J2, J3 dan J4 dengan arah kemiringan dan sudut kemiringan sebanyak masing-masing $323^{\circ} / 44^{\circ}, 125^{\circ} / 57^{\circ}, 42^{\circ} / 76^{\circ}, 263^{\circ} / 67^{\circ}$. Hubungan antara kualiti jasad batuan, nilai $Q$ dan lebar gua menunjukkan bahawa semua bahagian di dalam gua memerlukan sokongan kecuali ruang gua di bahagian utara. Bagi kestabilan dinding gua, bahagian utara dinding tenggara, bahagian tenggara dan selatan serta dinding barat laut dan bahagian barat daya dikelaskan sebagai kelas cerun tidak baik disebabkan oleh orientasi dinding gua yang kurang baik. Nisbah ketebalan bumbung gua berbanding dengan lebar gua menunjukkan bahawa gua dalam keadaan stabil. Daripada hasil kajian ini, satu pelan mitigasi telah dicadangkan untuk menyorotkan zon keselamatan gua untuk memastikan keselamatan para penganut dan orang awam yang mengunjungi gua tersebut.

Kata kunci: Kestabilan gua; ketebalan bumbung gua; mitigasi; Perkadaran Jasad Batuan (SMR); Sistem-Q

\section{INTRODUCTION}

Naga Mas Cave is located in Perak, Malaysia (Figure 1) at the coordinates of $4^{\circ} 30 ' 27.4^{\prime \prime} \mathrm{N} 101^{\circ} 08^{\prime} 54.8^{\prime \prime} \mathrm{E}$ and becoming one of the attractive tourist destinations from all around Malaysia. The study area consists of two levels and Naga Mas Cave is a cave located at upper level. A small prayer space for worship activity is located at ground level. The cave authority is planning to build a mega spiral staircase on the limestone rock slope to connect the ground level to level one. Therefore, geological input is very important for the project to ensure the public's safety, given the fact that cave stability issues receive less attention by the community. Previously, cave stability has been studied by Waltham (2002) in which a cave is categorized as stable when the cave roof thickness-width ratio is more than 0.7. In Malaysia, only 


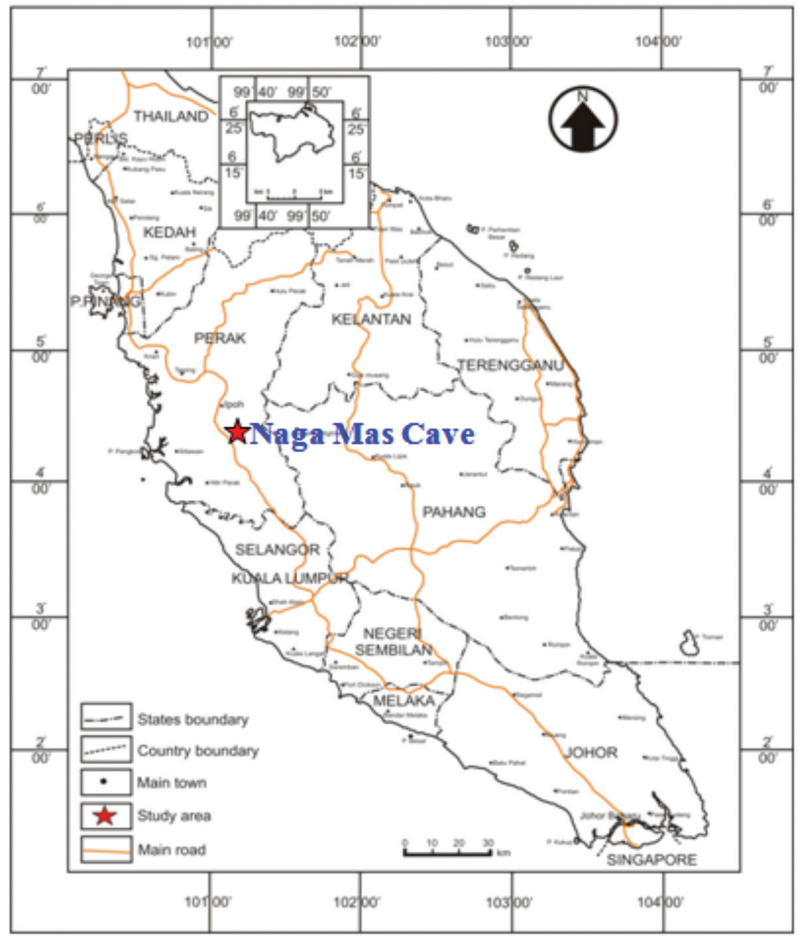

FIGURE 1. Location of study

Ailie et al. (2015), Goh et al. (2018, 2016a, 2016b), and Nur Amanina et al. (2016) assessed the stability of Gua Damai, Selangor and Kek Look Tong Cave, Perak based on Waltham's (2002) recommendations and integrated with Slope Mass Rating (SMR) method. Therefore, in this study, integrated cave stability assessment on Naga Mas Cave was adopted to ensure the safety of public.

\section{GEOLOGY SETTING}

The study area is regarded as a part of the Kinta Valley Formation as suggested by Foo (1983) based on the large limestone distribution which dominates the Kinta Valley area. According to Foo (1983), Kinta limestone is equivalent to Baling group located in Northern Peninsular Malaysia. Facies of the study area is similar with the facies found in Sungai Siput area. Previously, H.S Lee Beds, Nam Long Beds, Thye Onn Beds, Kuan Onn Beds and Kanthan Limestone have been used to describe the Kinta Limestone. Foo (1983) suggested that the age of Kinta Limestone is Silurian to Permian. The age of the Kinta Limestone was determined by the presence of fossils. In the Kampar area, argillite facies consists of black shale and argillic sandstone which were named as Kim Long Bed No.1 by Suntharalingam (1968) are found. A detailed study of the stratigraphy of the west of Kampar shows an apparent continuous Devonian to Permian succession of limestone. According to Metcalfe (1981), an unconformity boundary exists between Devonian and Carboniferous.

\section{MATERIALS AND METHODS}

\section{CAVE MAPPING}

Cave mapping was conducted to determine the cave geometry, shape and cave structure by measuring the width and height of the cave using a Bosch Laser Rangefinder. The thickness of roof was obtained based on the difference between height from Rangefinder survey and elevation topographic map. Cave orientation such as dips direction and dips were measured with a geological compass.

\section{CAVE STABILITY ASSESSMENT}

Cave stability was analyzed in terms of cave width, cave roof thickness and cave width ratio and the Q-system. According to Waltham (2002), the limestone roof thickness should not exceed $70 \%$ of the cave width. This mean than cave with cave roof thickness and cave width ratio exceed 0.7 is not stable. Cave roof thickness and cave width ratio can be calculated by using (1). Next, Q-values were plotted in Waltham (2002) graph for assessment of cave stability.

$$
\text { Cave Roof and Width Ratio }=\frac{\text { Cave roof thickness }}{\text { Cave width }}
$$

The cave wall stability were determined by using Slope Mass Rating (SMR) as the different cave orientation will provide a different value for the Slope Mass Rating. Additionally, Q-values (Barton 1995) were calculated which correlates the full Rock Mass Rating $\left(\mathrm{RMR}_{\text {full }}\right)$ value by using (2). Full Rock Mass Rating $\left(\mathrm{RMR}_{\text {full }}\right)$ including 
the effect of discontinuity strike and dip orientation found from kinematic analysis in tunneling.

$$
\mathrm{RMR}_{\text {full }}=15 \log \mathrm{Q}+50
$$

\section{CAVE WALL ASSESSMENT BY USING SLOPE MASS RATING (SMR)}

Slope Mass Rating (Romana 1985) was used to assess the cave wall stability. It is an additional application of Rock Mass Rating (Bieniawski 1989). This method involved the following steps: $\mathrm{RMR}_{\text {basic }}$ (Bieniawski 1989); Parallelism between discontinuity, $\alpha \mathrm{j}$ (or the intersection line, $\alpha \mathrm{i}$, in the case of wedge failure) and slope dip direction (F1); Discontinuity dip $(\beta j)$ in the case of planar failure and the plunge, $\beta \mathrm{i}$ of the intersection line in wedge failure (F2); Relationship between slope $(\beta \mathrm{s})$ and discontinuity $(\beta \mathrm{j})$ dips (toppling or planar failure cases) or the immersion line dip ( $\beta \mathrm{i})$. (F3); and correction factor that depends on the excavation method used (F4).

Slope Mass Rating can be calculated by:

$$
\mathrm{SMR}=\mathrm{RMR}_{\text {basic }}+(\mathrm{F} 1 \times \mathrm{F} 2 \times \mathrm{F} 3)+\mathrm{F} 4
$$

\section{RESULTS AND DISCUSSION}

The natural cave of Naga Mas Cave consist of a main cave and a small cave chamber which is located beside the main cave (Figure 2). The main cave has been divided into 14 parts, labeled with alphabets $\mathrm{A}$ to $\mathrm{N}$ while the chamber is divided into 3 parts, labeled with alphabets $\mathrm{X}$ to $\mathrm{Z}$. Each part is located 3 meters apart.

\section{KINEMATIC ANALYSIS}

The discontinuities survey was conducted on C1 and C2 slope (Figure 2) at Naga Mas Cave. The discontinuity survey shows that the slope $\mathrm{C} 1$ has three sets of joints $\mathrm{J} 1, \mathrm{~J} 2$ and $\mathrm{J} 3$ with the dip direction and dip angles of $332^{\circ} / 49^{\circ}, 154^{\circ} / 37^{\circ}$ and $049^{\circ} / 80^{\circ}$ (Figure 3) while slope $\mathrm{C} 2$ has four sets of joints $\mathrm{J} 1, \mathrm{~J} 2, \mathrm{~J} 3$ and $\mathrm{J} 4$ with the dip direction and dip angles of $323^{\circ} / 44^{\circ}, 125^{\circ} / 57^{\circ}, 42^{\circ} / 76^{\circ}$ and $263^{\circ} / 67^{\circ}$, respectively (Figure 3 ). Peak friction angles for the discontinuity surfaces for slope $\mathrm{C} 1$ is $50^{\circ}$ while slope $\mathrm{C} 2$ is $55^{\circ}$ were determined based on the recommendation of Ailie et al. (2017).

\section{CAVE STABILITY ASSESSMENT}

The Uniaxial Compression Strength (UCS) value for material failure is in the range of $50.5 \mathrm{MPa}-80.3 \mathrm{MPa}$.
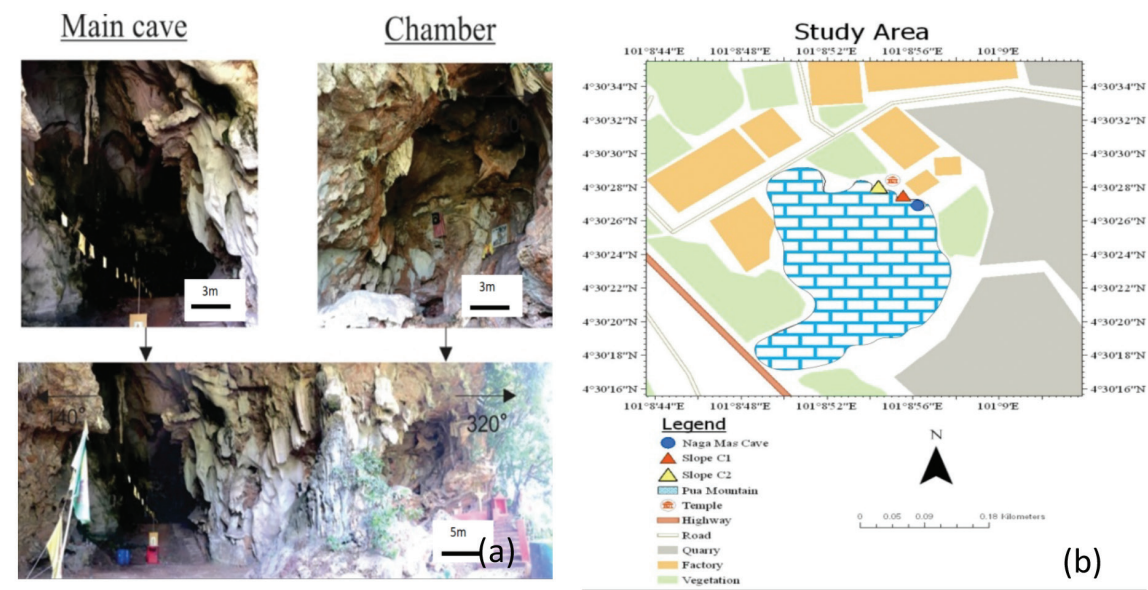

FIGURE 2. (a) Structure of Naga Mas Cave, Mount Pua, Kinta Valley, Ipoh, Perak, Malaysia which includes main cave and cave chamber (b) Location of slope 1 (C1), slope 2 (C2) and Naga Mas Cave

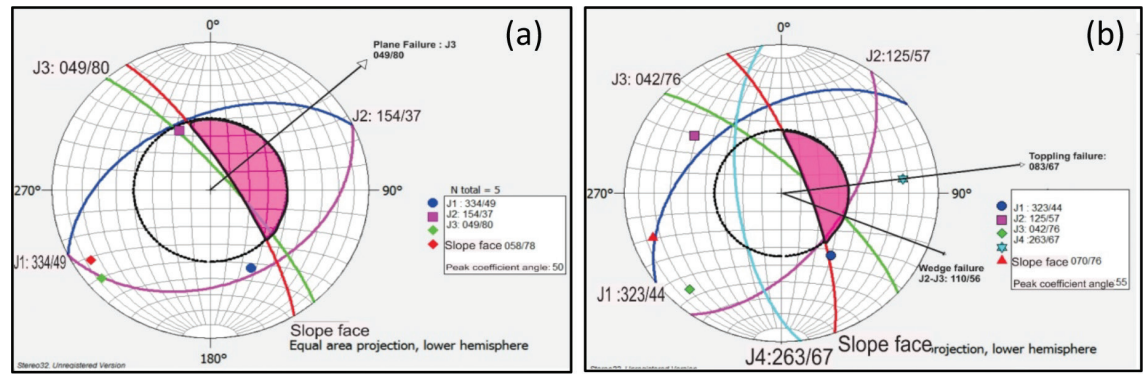

FIGURE 3. (a) Stereoplot of slope C1. The dip direction and dip of J1, J2 and J3 are $332^{\circ} / 49^{\circ}$, $154^{\circ} / 37^{\circ}$ and $049^{\circ} / 80^{\circ}$, respectively, (b) Stereoplot of slope C2. The dip direction and dip of J1, $\mathrm{J} 2, \mathrm{~J} 3$ and $\mathrm{J} 4$ are $323^{\circ} / 44^{\circ}, 125^{\circ} / 57^{\circ}, 42^{\circ} / 76^{\circ}$ and $263^{\circ} / 67^{\circ}$, respectively 
An average reading $59.7 \mathrm{MPa}$ is taken as the reference value for tabulation of data. The basic rock mass rating $\left(\mathrm{RMR}_{\text {basic }}\right.$ ) for slope $\mathrm{C} 1$ and slope $\mathrm{C} 2$ that have undergone material failure were 63 and $73 . \mathrm{RMR}_{\text {basic }}$ for both slope $\mathrm{C} 1$ and C2 (Tables 1 and 2) were classified as good or class II rock. The rating adjustment for discontinuities orientation has been set for tunnels.

Based on the results of $\mathrm{RMR}_{\text {basic }}$, a total of 24 cave walls in the main cave and cave chamber were assessed by using the Slope Mass Rating classification system. The cave walls were classified from class II to IV in Slope Mass Rating (Romana 1985) (Table 3). For the sections A-D, I-M, E'-J' and N- N' the rating was poor. Figure 4 shows that Slope Mass rating for 24 cave walls in Naga Mas Cave.

From the calculation of cave thickness and cave width ratio (Waltham 2002), the highest ratio is 6.3 while the lowest is 0.9 (Figure 4). The lowest ratio is located at the peak of the cave roof. In general, the cave thickness and cave width ratio in Naga Mas Cave exceed 0.7. This result shows that the cave roof of Naga Mas Cave is stable and safe. From the assessment based on the Q-value (Barton et al. 1974) and cave width (Figure 5), supports are needed to apply on all parts in the cave except part Z. Q-values range from 0.46 to 4.64 based on the varies orientation on cave wall. Different cave wall orientation results different Q-value.

In conclusion, the chamber is more stable compared to the main cave in Naga Mas Cave. The combination among 3 important parameters include Q-value, Slope Mass Rating (SMR) and cave roof thickness to cave width ratio have been integrated for analysis as shown in Figure 5.

A mitigation plan has been proposed for Naga Mas Cave by using updated Q-support chart of Grimstad and Barton (1993) (Figure 6 \& Table 4). Part M', Y, Y', Z are the most stable part where support is not needed on these parts. Meanwhile, systematic bolting and reinforced shotcrete at thickness of 4-10 $\mathrm{cm}$ with bolt spacing, 1.8 $\mathrm{m}$ are needed for part A, B, C, A', C', D', E', F', G', H', I', J', K' and L' while systematic bolting and reinforced

TABLE 1. Results of assessment of RMR basic at C1, Naga Mas Cave, Mount Pua, Kinta Valley, Ipoh, Perak, Malaysia

\begin{tabular}{lcc}
\hline \multirow{2}{*}{ Parameter } & \multicolumn{2}{c}{ Material failure } \\
\cline { 2 - 3 } & Value & Rating \\
\hline Uniaxial compressive strength, UCS (MPa) & 59.7 & 7 \\
Rock quality designation, RQD & $87 \%$ & 17 \\
Spacing (mm) & 160 & 8 \\
Discontinuity condition & & \\
Persistence (m) & 1.9 & 4 \\
Aperture (mm) & $6-20$ & 0 \\
Roughness & Slightly rough & 3 \\
Infilling & No & 6 \\
Weathering & Moderate & 3 \\
Groundwater condition & Dry & 15 \\
RMR & II (Good) & 63 \\
\hline
\end{tabular}

TABLE 2. Results of assessment of RMR basic at C2, Naga Mas Cave, Mount Pua, Kinta Valley, Ipoh, Perak, Malaysia

\begin{tabular}{lcc}
\hline \multicolumn{1}{c}{ Parameter } & \multicolumn{2}{c}{ Material failure } \\
\cline { 2 - 3 } & Value & Rating \\
\hline Uniaxial compressive strength, UCS & & \\
(MPa) & 59.7 & 7 \\
Rock quality designation, RQD & $90 \%$ & 20 \\
Spacing (mm) & 190 & 8 \\
Discontinuity condition & & \\
Persistence (m) & & 4 \\
Aperture (mm) & 2.0 & 5 \\
Roughness & $<1$ & 5 \\
Infilling & Rough \\
Weathering & No & 6 \\
Groundwater condition & Moderate \\
RMR ${ }_{\text {basic }}$ & Dry & 3 \\
\hline
\end{tabular}


TABLE 3. Summary of Slope Mass Rating, SMR

\begin{tabular}{|c|c|c|c|c|c|c|c|c|c|}
\hline Slope & $\begin{array}{c}\text { Weathering } \\
\text { grade }\end{array}$ & Type of failure & $\begin{array}{l}\text { Mode of } \\
\text { failure }\end{array}$ & Joint set & $\begin{array}{c}\text { Joint } \\
\text { orientation }\end{array}$ & Slope face & RMR & SMR & Class \\
\hline \multirow[t]{4}{*}{ A-B } & \multirow[t]{4}{*}{ II } & $\mathrm{M}$ & Wedge & $\mathrm{J} 1-\mathrm{J} 3$ & $324 / 47$ & $310 / 70$ & 63 & 36 & IV \\
\hline & & MD & Wedge & J1-J3 & $324 / 47$ & $310 / 70$ & 60 & 33 & IV \\
\hline & & $\mathrm{M}$ & Wedge & J3-J4 & $326 / 49$ & $310 / 70$ & 63 & 36 & IV \\
\hline & & MD & Wedge & J3-J4 & $326 / 49$ & $310 / 70$ & 60 & 33 & IV \\
\hline \multirow[t]{4}{*}{ B-C } & \multirow[t]{4}{*}{ II } & $\mathrm{M}$ & Wedge & J1-J3 & $324 / 47$ & $308 / 70$ & 63 & 36 & IV \\
\hline & & MD & Wedge & J1-J3 & $324 / 47$ & $308 / 70$ & 60 & 33 & IV \\
\hline & & $\mathrm{M}$ & Wedge & J3-J4 & $326 / 49$ & $308 / 70$ & 63 & 36 & IV \\
\hline & & MD & Wedge & J3-J4 & $326 / 49$ & $308 / 70$ & 60 & 33 & IV \\
\hline \multirow[t]{4}{*}{ C-D } & \multirow[t]{4}{*}{ III } & M & Wedge & $\mathrm{J} 1-\mathrm{J} 3$ & $324 / 47$ & $308 / 72$ & 63 & 36 & IV \\
\hline & & MD & Wedge & $\mathrm{J} 1-\mathrm{J} 3$ & $324 / 47$ & $308 / 72$ & 60 & 33 & IV \\
\hline & & M & Wedge & J3-J4 & $326 / 49$ & $308 / 72$ & 63 & 36 & IV \\
\hline & & MD & Wedge & J3-J4 & $326 / 49$ & $308 / 72$ & 60 & 33 & IV \\
\hline \multirow[t]{6}{*}{ D-E } & \multirow[t]{6}{*}{ II } & M & Wedge & J1-J3 & $324 / 47$ & $280 / 65$ & 63 & 69 & II \\
\hline & & MD & Wedge & $\mathrm{J} 1-\mathrm{J} 3$ & $324 / 47$ & $280 / 65$ & 60 & 66 & II \\
\hline & & M & Wedge & J3-J4 & $326 / 49$ & $280 / 65$ & 63 & 69 & II \\
\hline & & MD & Wedge & J3-J4 & $326 / 49$ & $280 / 65$ & 60 & 66 & II \\
\hline & & $\mathrm{M}$ & Planar & $\mathrm{J} 4$ & $263 / 68$ & $280 / 65$ & 63 & 73.8 & IV \\
\hline & & MD & Planar & $\mathrm{J} 4$ & $263 / 68$ & $280 / 65$ & 60 & 70.8 & IV \\
\hline \multirow[t]{6}{*}{ E-F } & \multirow[t]{6}{*}{ II } & $\mathrm{M}$ & Wedge & J1-J3 & $324 / 47$ & $280 / 65$ & 63 & 69 & II \\
\hline & & MD & Wedge & $\mathrm{J} 1-\mathrm{J} 3$ & $324 / 47$ & $280 / 65$ & 60 & 66 & II \\
\hline & & $\mathrm{M}$ & Wedge & J3-J4 & $326 / 49$ & $280 / 65$ & 63 & 69 & II \\
\hline & & MD & Wedge & J3-J4 & $326 / 49$ & $280 / 65$ & 60 & 66 & II \\
\hline & & $\mathrm{M}$ & Planar & $\mathrm{J} 4$ & $263 / 68$ & $280 / 65$ & 63 & 73.8 & II \\
\hline & & MD & Planar & $\mathrm{J} 4$ & $263 / 68$ & $280 / 65$ & 60 & 70.8 & II \\
\hline \multirow[t]{4}{*}{ F-G } & \multirow[t]{4}{*}{ II } & $\mathrm{M}$ & Wedge & J1-J3 & $324 / 47$ & $287 / 68$ & 63 & 69 & II \\
\hline & & MD & Wedge & J1-J3 & $324 / 47$ & $287 / 68$ & 60 & 66 & II \\
\hline & & $\mathrm{M}$ & Wedge & J3-J4 & $326 / 49$ & $287 / 68$ & 63 & 69 & II \\
\hline & & MD & Wedge & J3-J4 & $326 / 49$ & $287 / 68$ & 60 & 66 & II \\
\hline \multirow[t]{4}{*}{ G-H } & \multirow[t]{4}{*}{ II } & $\mathrm{M}$ & Wedge & J1-J3 & $324 / 47$ & $290 / 68$ & 63 & 69 & II \\
\hline & & MD & Wedge & J1-J3 & $324 / 47$ & $290 / 68$ & 60 & 66 & II \\
\hline & & M & Wedge & J3-J4 & $326 / 49$ & $290 / 68$ & 63 & 69 & II \\
\hline & & MD & Wedge & J3-J4 & $326 / 49$ & $290 / 68$ & 60 & 66 & II \\
\hline \multirow[t]{6}{*}{ H-I } & \multirow[t]{6}{*}{ III } & B & Wedge & J1-J3 & $324 / 47$ & $270 / 68$ & 63 & 69 & II \\
\hline & & BK & Wedge & J1-J3 & $324 / 47$ & $270 / 68$ & 60 & 66 & II \\
\hline & & B & Wedge & J3-J4 & $326 / 49$ & $270 / 68$ & 63 & 69 & II \\
\hline & & BK & Wedge & J3-J4 & $326 / 49$ & $270 / 68$ & 60 & 66 & II \\
\hline & & B & Planar & $\mathrm{J} 4$ & $263 / 68$ & $270 / 68$ & 63 & 56.75 & III \\
\hline & & BK & Planar & $\mathrm{J} 4$ & $263 / 68$ & $270 / 68$ & 60 & 53.75 & III \\
\hline \multirow[t]{4}{*}{ I-J } & III & B & Wedge & J1-J3 & $324 / 47$ & $316 / 70$ & 63 & 27 & IV \\
\hline & & BK & Wedge & J1-J3 & $324 / 47$ & $316 / 70$ & 60 & 24 & IV \\
\hline & & B & Wedge & J3-J4 & $326 / 49$ & $316 / 70$ & 63 & 27 & IV \\
\hline & & BK & Wedge & J3-J4 & $326 / 49$ & $316 / 70$ & 60 & 24 & IV \\
\hline $\mathrm{J}-\mathrm{M}$ & III & $\mathrm{B}$ & Wedge & J1-J3 & $324 / 47$ & $318 / 70$ & 63 & 27 & IV \\
\hline & & BK & Wedge & J1-J3 & $324 / 47$ & $318 / 70$ & 60 & 24 & IV \\
\hline & & $\mathrm{B}$ & Wedge & J3-J4 & $326 / 49$ & $318 / 70$ & 63 & 27 & IV \\
\hline & & BK & Wedge & J3-J4 & $326 / 49$ & $318 / 70$ & 60 & 24 & IV \\
\hline$A^{\prime}-B^{\prime}$ & II & B & Wedge & J2-J3 & $122 / 43$ & $92 / 72$ & 63 & 57.6 & III \\
\hline & & $\mathrm{BK}$ & Wedge & $\mathrm{J} 2-\mathrm{J} 3$ & $122 / 43$ & $92 / 72$ & 60 & 54.6 & III \\
\hline & & B & Toppling & $\mathrm{J} 4$ & $263 / 68$ & $92 / 72$ & 63 & 56.75 & III \\
\hline & & BK & Toppling & $\mathrm{J} 4$ & $263 / 68$ & $92 / 72$ & 60 & 53.75 & III \\
\hline$B^{\prime}-C^{\prime}$ & II & B & Wedge & J2-J3 & $122 / 43$ & $95 / 76$ & 63 & 57.6 & III \\
\hline & & BK & Wedge & $\mathrm{J} 2-\mathrm{J} 3$ & $122 / 43$ & $95 / 76$ & 60 & 54.6 & III \\
\hline & & B & Toppling & $\mathrm{J} 4$ & $263 / 68$ & $95 / 76$ & 63 & 60.5 & III \\
\hline & & BK & Toppling & $\mathrm{J} 4$ & $263 / 68$ & $95 / 76$ & 60 & 57.5 & III \\
\hline
\end{tabular}


(Continued) TABLE 3.

\begin{tabular}{|c|c|c|c|c|c|c|c|c|c|}
\hline Slope & $\begin{array}{l}\text { Weathering } \\
\text { grade }\end{array}$ & Type of failure & $\begin{array}{l}\text { Mode of } \\
\text { failure }\end{array}$ & Joint set & $\begin{array}{c}\text { Joint } \\
\text { orientation }\end{array}$ & Slope face & RMR & SMR & Class \\
\hline \multirow[t]{4}{*}{$C^{\prime}-D^{\prime}$} & \multirow[t]{4}{*}{$\mathrm{I}$} & $\mathrm{M}$ & Wedge & $\mathrm{J} 2-\mathrm{J} 3$ & $122 / 43$ & $86 / 62$ & 63 & 70.35 & III \\
\hline & & MD & Wedge & $\mathrm{J} 2-\mathrm{J} 3$ & $122 / 43$ & $86 / 62$ & 60 & 67.35 & III \\
\hline & & $\mathrm{M}$ & Toppling & $\mathrm{J} 4$ & $263 / 68$ & $86 / 62$ & 63 & 60.5 & II \\
\hline & & MD & Toppling & $\mathrm{J} 4$ & $263 / 68$ & $86 / 62$ & 60 & 57.5 & III \\
\hline \multirow[t]{4}{*}{ D-E } & \multirow[t]{4}{*}{ I } & $\mathrm{M}$ & Wedge & $\mathrm{J} 2-\mathrm{J} 3$ & $122 / 43$ & $85 / 62$ & 63 & 70.35 & II \\
\hline & & MD & Wedge & $\mathrm{J} 2-\mathrm{J} 3$ & $122 / 43$ & $85 / 62$ & 60 & 67.35 & II \\
\hline & & $\mathrm{M}$ & Toppling & $\mathrm{J} 4$ & $263 / 68$ & $85 / 62$ & 63 & 53 & III \\
\hline & & MD & Toppling & $\mathrm{J} 4$ & $263 / 68$ & $85 / 62$ & 60 & 50 & III \\
\hline \multirow[t]{2}{*}{$E^{\prime}-F^{\prime}$} & \multirow[t]{2}{*}{ I } & $\mathrm{M}$ & Wedge & $\mathrm{J} 2-\mathrm{J} 3$ & $122 / 43$ & $130 / 60$ & 63 & 34.65 & IV \\
\hline & & MD & Wedge & $\mathrm{J} 2-\mathrm{J} 3$ & $122 / 43$ & $130 / 60$ & 60 & 31.65 & IV \\
\hline \multirow[t]{2}{*}{$F^{\prime}-G^{\prime}$} & \multirow[t]{2}{*}{ II } & $\mathrm{M}$ & Wedge & $\mathrm{J} 2-\mathrm{J} 3$ & $122 / 43$ & $130 / 62$ & 63 & 34.65 & IV \\
\hline & & MD & Wedge & $\mathrm{J} 2-\mathrm{J} 3$ & $122 / 43$ & $130 / 62$ & 60 & 31.65 & IV \\
\hline \multirow[t]{2}{*}{ G'-H' } & \multirow[t]{2}{*}{ III } & $\mathrm{M}$ & Wedge & $\mathrm{J} 2-\mathrm{J} 3$ & $122 / 43$ & $127 / 62$ & 63 & 34.65 & IV \\
\hline & & MD & Wedge & $\mathrm{J} 2-\mathrm{J} 3$ & $122 / 43$ & $127 / 62$ & 60 & 31.65 & IV \\
\hline \multirow[t]{2}{*}{ H'-I' } & \multirow[t]{2}{*}{ III } & $\mathrm{M}$ & Wedge & $\mathrm{J} 2-\mathrm{J} 3$ & $122 / 43$ & $127 / 62$ & 63 & 34.65 & IV \\
\hline & & MD & Wedge & $\mathrm{J} 2-\mathrm{J} 3$ & $122 / 43$ & $127 / 62$ & 60 & 31.65 & IV \\
\hline \multirow[t]{2}{*}{$I^{\prime}-J$ ' } & \multirow[t]{2}{*}{ II } & $\mathrm{M}$ & Wedge & $\mathrm{J} 2-\mathrm{J} 3$ & $122 / 43$ & $134 / 58$ & 63 & 42.3 & III \\
\hline & & MD & Wedge & $\mathrm{J} 2-\mathrm{J} 3$ & $122 / 43$ & $134 / 58$ & 60 & 39.3 & IV \\
\hline \multirow[t]{2}{*}{$\mathrm{J}^{\prime}-\mathrm{K}^{\prime}$} & \multirow[t]{2}{*}{ II } & $\mathrm{M}$ & Wedge & J2-J3 & $122 / 43$ & $143 / 68$ & 63 & 57.6 & III \\
\hline & & MD & Wedge & $\mathrm{J} 2-\mathrm{J} 3$ & $122 / 43$ & $143 / 68$ & 60 & 54.6 & III \\
\hline \multirow[t]{2}{*}{$\mathrm{K}^{\prime}-\mathrm{L}^{\prime}$} & \multirow[t]{2}{*}{ III } & $\mathrm{M}$ & Wedge & $\mathrm{J} 2-\mathrm{J} 3$ & $122 / 43$ & $150 / 74$ & 63 & 57.6 & III \\
\hline & & MD & Wedge & $\mathrm{J} 2-\mathrm{J} 3$ & $122 / 43$ & $150 / 74$ & 60 & 54.6 & III \\
\hline \multirow[t]{2}{*}{$X-Y$} & \multirow[t]{2}{*}{ II } & $\mathrm{M}$ & - & - & - & $30 / 60$ & 63 & 63 & II \\
\hline & & MD & - & - & - & $30 / 60$ & 60 & 60 & III \\
\hline \multirow[t]{2}{*}{$\mathrm{Y}-\mathrm{Z}$} & \multirow[t]{2}{*}{ II } & $\mathrm{M}$ & - & - & - & $30 / 61$ & 63 & 63 & II \\
\hline & & MD & - & - & - & $30 / 61$ & 60 & 60 & III \\
\hline \multirow[t]{2}{*}{$X^{\prime}-Y^{\prime}$} & \multirow[t]{2}{*}{ II } & $\mathrm{M}$ & - & - & - & $180 / 60$ & 63 & 63 & II \\
\hline & & MD & - & - & - & $180 / 60$ & 60 & 60 & III \\
\hline \multirow[t]{2}{*}{$Y^{\prime}-Z$} & \multirow[t]{2}{*}{ II } & $\mathrm{M}$ & - & - & - & $182 / 59$ & 63 & 63 & II \\
\hline & & MD & - & - & - & $182 / 59$ & 60 & 60 & III \\
\hline
\end{tabular}

M: Material Failure; MD: Material and Discontinuity
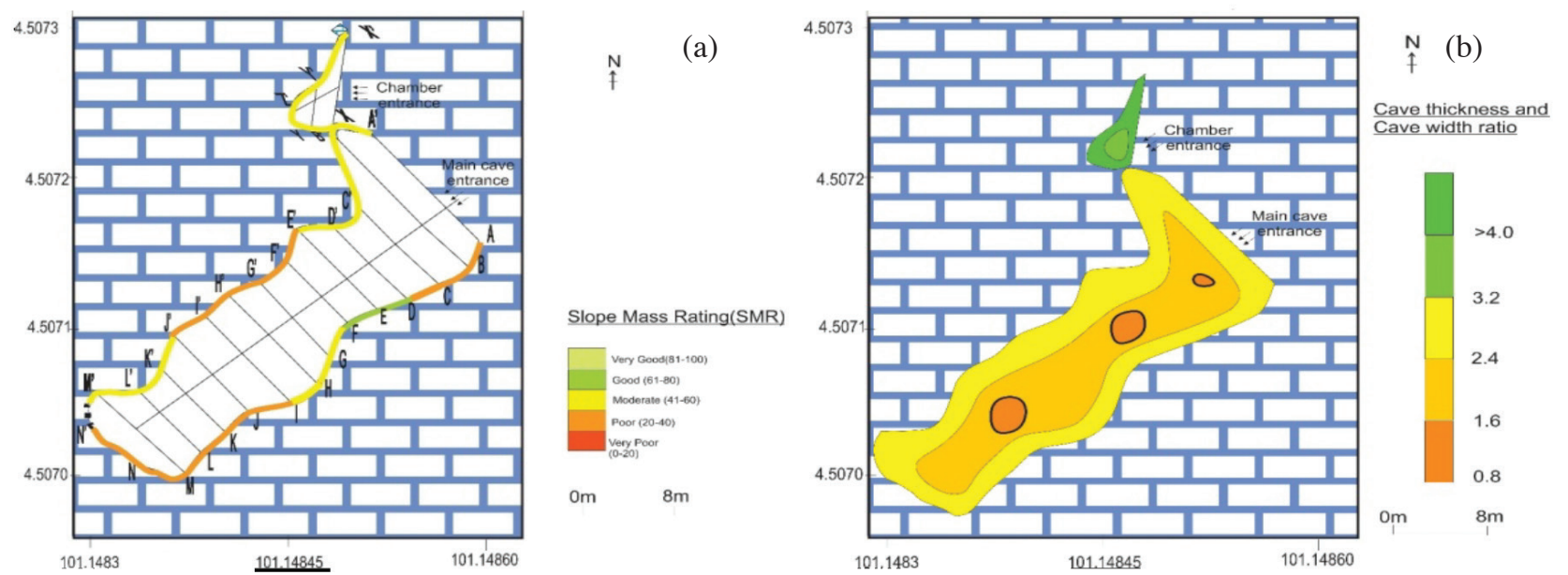

FIGURE 4. (a) Slope mass rating (SMR) (b) Contour created based on cave roof thickness and cave width ratio, Naga Mas Cave, Mount Pua, Kinta Valley, Ipoh, Perak, Malaysia 

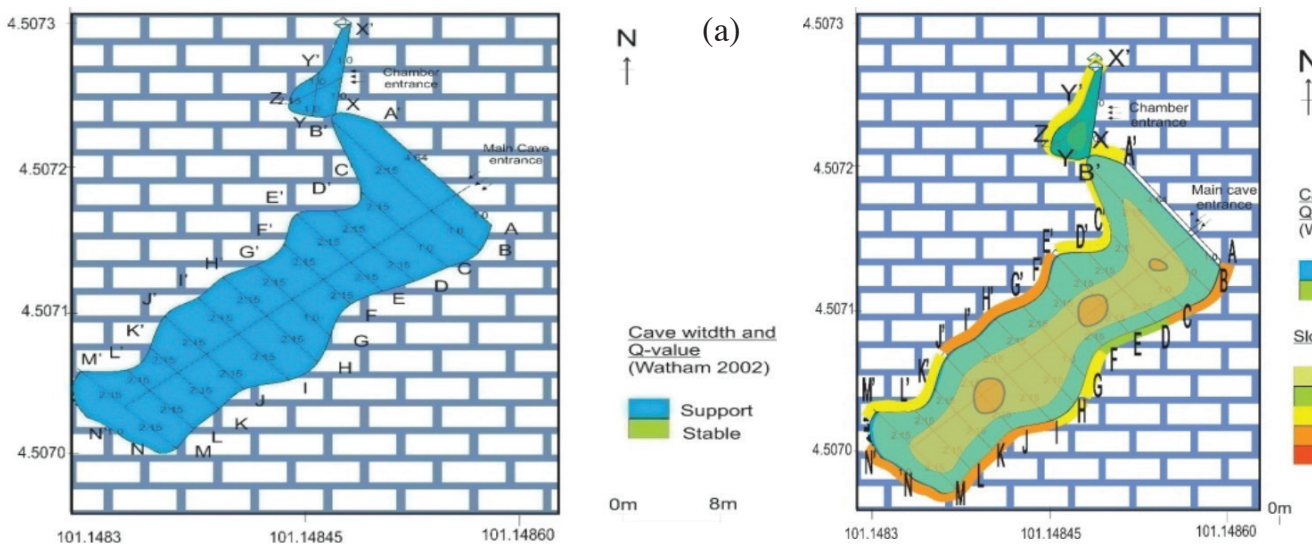

(b)

FIGURE 5. (a) Summary of cave width with Q-value (b) Mitigation plan on part A-N Naga Mas Cave, Mount Pua, Kinta Valley, Ipoh, Perak, Malaysia

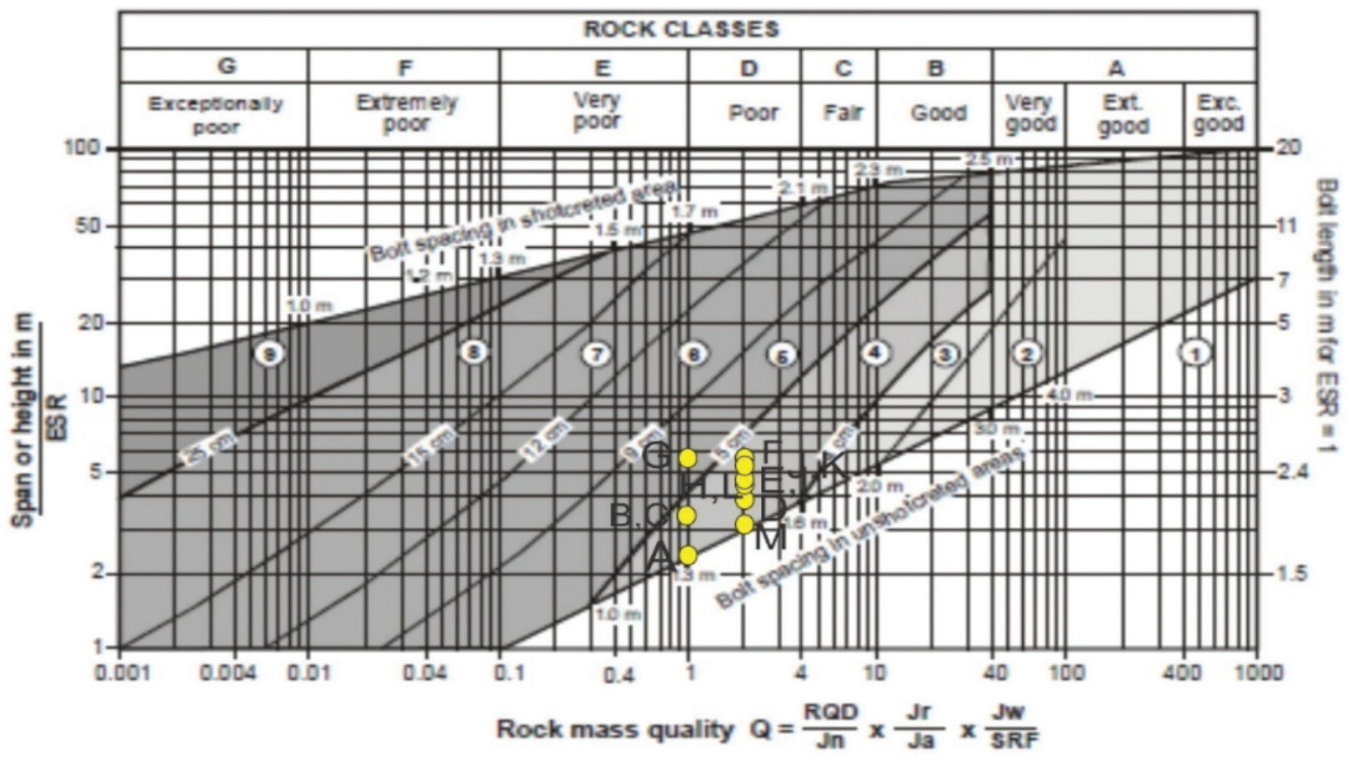

\begin{tabular}{|c|c|}
\hline \multicolumn{2}{|l|}{ REINFORCEMENT CATEGORIES: } \\
\hline 1) Unsupported & 6) Fibre reinforced shotcrete and boiting, $9-12 \mathrm{~cm}$ \\
\hline 2) Ipot bolting & 7) Flbre reinforced shotcrete and bolting, $12-15 \mathrm{~cm}$ \\
\hline 3) aystematic botting & 8) Flbre reinforced ahotcrete, $>15 \mathrm{~cm}$, \\
\hline 4) aystematic boting. (and unreinforced shotcrete, 4- $10 \mathrm{~cm}$ ) & reinforced rba of shotcrete and botting \\
\hline 5) Fbre reinforced shoturete and boiting. $5-9 \mathrm{~cm}$ & 9) cast concrese lining \\
\hline
\end{tabular}

Source: Modified from Grimstad \& Barton (1993)

FIGURE 6. Proposed mitigation for Naga Mas Cave, Mount Pua, Kinta Valley, Ipoh, Perak, Malaysia

TABLE 4. Suggestion of mitigation plan for cave wall in Naga Mas Cave, Mount Pua, Kinta Valley, Ipoh, Perak, Malaysia based on updated Q-support chart of Grimstad and Barton (1993)

\begin{tabular}{lcl}
\hline \multicolumn{1}{c}{ Reinforcement categories } & Bolt spacing & \multicolumn{1}{c}{ Part } \\
\hline Unsupported & - & M', Y, Y', Z \\
Systematic bolting (and reinforced shotcrete $4-10 \mathrm{~cm})$ & $1.8 \mathrm{~m}$ & A, B, C, A', C', D', E', F', G', H', I', J', K' and L' \\
Systematic bolting (and reinforced shotcrete $4-10 \mathrm{~cm}$ ) & $1.9 \mathrm{~m}$ & D, E, F, H, I, J, K, L, M and N, \\
Systematic bolting (and reinforced shotcrete $4-10 \mathrm{~cm}$ & $2.0 \mathrm{~m}$ & $\mathrm{~N}^{\prime}$ \\
Fibre reinforced shotcrete and Bolting $(5-9 \mathrm{~cm})$ & $1.7 \mathrm{~m}$ & B' \\
\hline
\end{tabular}


shotcrete at thickness of 4-10 cm with bolt spacing, 1.9 $\mathrm{m}$ are suitable for part D, E, F, H, I, J, K, L, M and N. Systematic bolting and reinforced shotcrete at thickness of $4-10 \mathrm{~cm}$ with bolt spacing, $2.0 \mathrm{~m}$ is suggested to implement on Part N' whereas part B' is suggested to mitigate by using fibre reinforced shotcrete and bolting $(5-9 \mathrm{~cm})$ with bolt spacing, $1.7 \mathrm{~m}$. Excavation support ratio (ESR) (Barton et al. 1974) used in the analysis is 1.3 which used to excavate for storage room, water treatment plants, railway tunnel and access tunnels.

\section{CONCLUSION}

As conclusion, this study and its findings offer a reliable, low cost approach to assessment the stability of cave and cave wall. Geomorphological features need to be conserved to raise the geotourism value and ensuring public safety at the same time. Suggestion for mitigation includes the factor that limestone cave is a highlighted tourist spot by Perak State Government and limestone cave in Kinta Valley is vital element in Kinta Geopark. To conserve the cave morphological features, setting up active netting is more suitable compare with applying the reinforced shotcrete which reinforced shotcrete would cover the natural and beauty of geomorphological feature on cave wall.

\section{ACKNOWLEDGEMENTS}

The authors wish to thank the lab staff of the Geology Program, Universiti Kebangsaan Malaysia for financial assistant under GUP-2018-116 and Universiti Kebangsaan Malaysia Sabbatical leave program.

\section{REFERENCES}

Ailie, S.S., Goh, T.L., Abdul, G.R., Azimah, H., Lee, K.E. \& Tuan, R.M. 2017. Peak friction angle estimation from joint roughness coefficient of discontinuities of limestone in Peninsular Malaysia. Sains Malaysiana 46(2): 181-188.

Ailie, S.S., Goh, T.L., Norbert, S., Abdul, G.R., Tuan, R.M. \& Noraini, S. 2015. Rockfall and Sustainable Development: A case study at Gua Damai, Selangor, Malaysia. Prosiding Persidangan Regional Geoheritage p. 69.

Barton, N. 1995. The influence of joint properties in modelling jointed rock masses. 8th ISRM Congress 3(3): 1023-1032.

Barton, N., Lien, R. \& Lunde, J. 1974. Engineering classification of rock mass for design of tunnel support. Rock Mechanics 6: 189-236.

Bieniawski, Z.T. 1989. Engineering Rock Mass Classifications: A Complete Manual for Engineers and Geologists in Mining, Civil, and Petroleum Engineering. New York: John Wiley $\&$ Sons Inc.

Foo, K.Y. 1983. The Palaezoic sedimentary rocks of Penisular Malaysia-Stratigraphy and correlation. Proceeding of the Workshop on Stratigraphic Correlation of Thailand and Malaysia (Malaysia and Associated Mineralization) 1:1-19.

Goh, T.L., Wong, J.M., Norbert, S., Abdul, G.R., Ailie, S.S., Nur, A.M., Ainul, M.R., Azimah, H. \& Tuan, R.M. 2018. Stability assessment of limestone cave: Batu Caves, Selangor, Malaysia. Sains Malaysiana 47(1): 59-66.
Goh, T.L., Ainul, M.R., Nur Amalina, M., Abdul, G.R., NurAilie, S.S. \& Tuan, R.M. 2016a. Rock slope stability assessment using slope mass rating (SMR) method: Gunung Lang Ipoh Malaysia. Scholars Journal of Engineering and Technology (SJET) 4(4): 185-192.

Goh, T.L., Wong, J.M., Norbert, S., Abdul, G.R., Ailie, S.S. \& Lee, K.E. 2016b. Stability assessment of limestone cave in Gua Damai, Batu Caves Selangor. National Geoscience Conference.p. 185.

Grimstad, E. \& Barton, N. 1993. Updating the Q-System for NMT. Proc. Int. Symp Metcalfe, I. 1981. Permian and Early Triassic conodonts from Northwest Peninsular Malaysia. Bull. Geol. Soc. Malaysia 14: 119-126.

Nur, A.M., Goh, T.L., Ainul, M.R., Muhammad Fahmi, A.G. \& Tuan, R.M. 2016. Cave stability assessment using slope mass rating and Q system in Kek Look Tong cave, Kinta Valley, Perak. National Geoscience Conference. pp. 76-80.

Romana, M. 1985. New adjustment ratings for application of Bieniawski classification to slopes. Proceedings of the International Symposium on the Role of Rock Mechanics. pp. 49-53.

Suntharalingam, T. 1968. Upper Palaeozoic stratigraphy of the area west of Kampar, Perak. Bull.Ceol. Soc.Malaysia 1: 1-15.

Waltham, T. 2002. The engineering classification of karst with respect to the role and influence of caves. Int. J. Speleol. 31(14): 19-35.

Goh Thian Lai*, Lok Kah Kit \& Azimah Hussin

Centre for Earth Sciences and Environment

Faculty of Science and Technology

Universiti Kebangsaan Malaysia

43600 UKM Bangi, Selangor Darul Ehsan

Malaysia

Ailie Sofyiana Serasa

School of Engineering

Asia Pacific University of Technology and Innovation (APU)

Technology Park Malaysia

57000 Bukit Jalil, Kuala Lumpur, Federal Territory

Malaysia

Abdul Ghani Rafek

Engineering Geology Advisory

11, SS21/12, Damansara Utama

47400 Petaling Jaya, Selangor Darul Ehsan

Malaysia

Lee Khai Ern

Institute for Environment and Development (LESTARI)

Universiti Kebangsaan Malaysia

43600 UKM Bangi, Selangor Darul Ehsan

Malaysia

Tuan Rusli Mohamed

Jabatan Mineral dan Geosains Malaysia

Menara PJH, Tingkat 9 Jalan Tun Abdul Razak

Presint 2, 62000 Putrajaya

Malaysia 
Shao Lei

School of Ocean and Earth Science

Tongji University, Shanghai

China

Yanlong Chen \& Mingwei Zhang

State Key Laboratory for Geomechanics \&

Deep Underground Engineering

China University of Mining and Technology

Xuzhou 221116

China
*Corresponding author; email: gdsbgoh@gmail.com

Received: 13 March 2019

Accepted: 15 August 2019 